\title{
Constitutions, National Culture, and Rethinking Islamism
}

In 2013 the Egyptian economist and political commentator Galal Amin complained that the problem besetting Egypt was that some organizations, particularly the Muslim Brotherhood and the Salafis, wanted to subvert the "natural place of religion" and return Egypt to the "middle ages." Religion, he declares, "is a part of life but it is not life in its entirety." ${ }^{\text {B }}$ Bringing religion out from its natural place into the public sphere, Amin maintains, would lead to sorrow and distress, and would jeopardize the rights of Egypt's Coptic Christians. Political Islam, he continues, prevents Egyptfromundergoing a national and cultural revival: for religion to be a means of such a revival, it must remain in its proper place. ${ }^{3}$

The conception that religion needs to be kept in its proper place, and that what that proper place is can be readily understood by reasonable members of the populace, underscores modern secularist assumptions about the nature of religion. Such assumptions about religion see any calls for politicized religion such as Islamism as a subversion of the modern natural order of things. In this chapter, however, I argue that Islamism should not be seen as an antimodern aberration that does not respect the proper place of religion. Islamism should rather be seen as a political movement that has been molded by the concerns of the modern state. Both Islamists and secularists have a shared concern with delineating the relationship between religion and politics. Both seek to renegotiate the relationship between religion 
and politics and impose their vision of such a relationship on modern state structures, even if Islamists see that relationship as more heavily colored by Islamic norms.

Seeing Islamists and secularists as engaged in a similar project draws upon more recent theorizations of secularism. Such theorizations view secularism as the state's project of promoting an abstract notion of religion and its ongoing involvement in managing religion. Both secular and Islamist constitutions share statist perspectives that hold that it is the right of the state to decide what place religion should occupy and the kinds of rights and obligations that should be given and expected accordingly. This is not, however, to deny that there are differences in how constitutions and states, commonly defined as secular or Islamic, determine such boundaries and the rights and duties they attach to these norms.

One of the ways in which the relationship between religion and politics is defined is through constitutional texts and laws that are promulgated based on those constitutional texts. Constitutions often demarcate the relationship between religion and politics and determine who gets to speak for-and represent-both. Constitutions also establish the relationship between religion and national culture and claim to represent the will of the nation.

Constitutions are most often analyzed through the lens of their capacity to guarantee democracy and human rights. However, they should also be understood in terms of their power as foundational ideological statements. Constitutions reflect how national culture and its relationship to religion and to particular religious traditions are crafted. They therefore can be seen as the way that citizenship and its relationship to religion are fashioned in the service of state formation. The modern nation state is predicated on certain homogenizing concepts, such as national culture and the idea of the national will. Through them, the state legitimizes its claim to represent its citizens. Drawing on the work of Timothy Mitchell and James C. Scott, this chapter demonstrates that constitutions are a means by which modern states represent themselves as objectlike, to be viewed, rendered legible, mapped out, and understood. This applies to how the state wishes to be understood by members of its population and by other nation states.

\section{Constitutions, Ideology, and the Modern State}

During the late nineteenth and twentieth centuries, promulgating a constitution was an accepted norm in modern politics. Earlier views of democracy in the eighteenth century emphasized the importance of the rule of the majority and constitutionalism was seen as less democratic since it placed limits 
on the government. ${ }^{4}$ However, Hanna Lerner shows that, "today the idea of a fundamental transformation of a political regime or the creation of a new one, whether by revolutionary means or otherwise, that does not involve the drafting of a new constitution is unthinkable." ${ }^{.5}$ Almost two hundred countries have written or codified constitutions. A small number have not. ${ }^{6}$

Nathan Brown claims that "scholars stopped studying constitutions [more than a generation ago] because they increasingly seemed quixotic: if political authority was to be constrained, it would not be done with mere pieces of paper." Constitutions, he argues, do not reflect political reality. This is certainly the case in contemporary Egypt, where Egyptians are frequently arrested without a warrant, interrogated without a lawyer present, tortured, and detained for indefinite periods without charge. ${ }^{8}$

The relationship between a constitutional text and the interpretation and application of that text in law is a complex one. For example, Catharine A. MacKinnon shows that constitutional commitments to gender equality do not relate to the equality of the sexes in reality. Norway and Australia have some of the highest international rankings regarding gender equality, yet the former has no commitment to equality between men and women in its constitution and Australia has no formal written constitution. ${ }^{9}$ Furthermore, many countries with the lowest gender-equality rankings in the world—such as Malawi-have substantive provisions guaranteeing gender equality and equal rights for women and men.

Another reason for the contemporary popularity of constitutions is that constitutions are often seen as inherent to the concept of the rule of law, which is concerned with impeding the exercise of arbitrary power. ${ }^{10}$ Constitutions are commonly created to limit the arbitrary use of power since they provide a supralegal framework. Constitutional rules are different from ordinary legislation because they are, Lerner points out, "accorded higher status since they regulate the rules of the game, and determine the procedures by which ordinary laws can be enacted." 11 Thus, constitutional rules are less vulnerable to the will of governments for the reason that the amendment of constitutional articles is more involved than the writing of new legislation.

Rule by law does not itself guarantee the rule of law. ${ }^{12}$ In many states, law can actually facilitate the exercise of authoritarian power. An example of this relates to the amendments that were made to the Egyptian Constitution of 1971 in 2007. While these constitutional amendments were presented by the Egyptian state as leading to the strengthening of the rule of law, in fact they further entrenched authoritarian practices in the Egyptian order. Thus, while the Egyptian state ruled through the law, it was not a democratic state that protected civil liberties. ${ }^{13}$ 
Nathan J. Brown maintains that constitutional rules do not simply restrict power but enable it. Constitution writing of the late eighteenth century, he argues, empowered governments. Indeed, there is no causal relationship between either constitutions or constitutionalism and democracy. Brown contends that constitutions in the Arab world have generally been written in such a way as to increase the power of political authority as opposed to limiting it. In addition, while constitutions and constitutionalism are often platforms for the establishment of human rights, it is not inevitable that such provisions be included. ${ }^{14}$

The possibility of guaranteeing human rights and for providing the rule of law cannot therefore alone account for the important role that constitutions play in modern political systems. Constitutions must also be seen in terms of their power in the foundation of a new political order. For the Romans, Hannah Arendt asserts, the source of authority lay in the foundation of Rome and in its ancestors. Central to Roman politics was "the conviction of the sacredness of foundation, in the sense that once something has been founded it remains binding for all future generations." ${ }^{15}$ She contends that the act of revolution remains, in Western political history, the type of event for which the notion of a foundation is imperative. Like the Romans, Arendt argues, "Machiavelli and Robespierre felt founding was the central political action, the one great deed that established the public-political realm and made politics possible." ${ }^{16}$ Revolutions, she claims, are attempts to repair foundations and "to renew the broken thread of tradition." ${ }^{17}$ In the American Revolution, the founding fathers established a new polity, and the constitution confirmed and legalized this act of foundation. ${ }^{18}$ Reverence for the US Constitution has transformed the document into a "sacred symbol of nationhood." ${ }^{19}$ It founded the state and embodied the aspirations of a particular sector of society.

Ulrich Preuss claims that constitution making is the power to create a political order ex nihilo. Constitution making is a revolutionary act that both consolidates the achievements of the revolution and puts an end to the revolution that made the constitution possible. The relationship between the revolution and the constitution is therefore "ambivalent," since "the constitution is the final act of the revolution." ${ }^{\prime 20}$ Yet constitutions continue to be important beyond the time when they are formed. While the moment of foundation remains the source of the constitution's legitimacy, the constitution also serves to provide a map of the relationship that the state is to have with its citizens. The new constitutional order depends on articulating who constitutes the nation and what its political values are. 
Timothy Mitchell argues that, "in the metaphysics of capitalist modernity, the world is experienced in terms of an ontological distinction between physical reality and its representation." ${ }^{21}$ This distinction between reality and the modes by which reality is represented involves envisioning society as a political and conceptual structure that is separate from people themselves. Nineteenth-century Europeans were concerned with the representation of things, with guides, signs, maps, or sets of instructions. ${ }^{22}$ Mitchell shows that, when Egyptians visited Europe in the nineteenth century, everywhere they went, "everything seemed to be set up before one as though it were the model of the picture of something.,"23 Everything was arranged before an observing subject into a system of signification. In the colonial process, Mitchell argues, colonial powers would try and reorder Egypt as something "picture-like, legible, rendered available to political and economic calculation." 24

Constitutions can be seen as important examples of the process that Mitchell refers to. Constitutions have come to operate as signifiers. They have become a means by which the state and national culture are represented. A constitution is representative of a political and conceptual structure that exists apart from the people themselves. Countries use constitutions to exhibit themselves to other countries and establish their legitimacy in the international system and render themselves amenable to political calculation. Via the constitution, those who control the state can signal to the rest of the populace what it stands for, and thus the constitution serves as a mechanism for disciplinary control. Constitutional texts can condition the populace by creating certain expectations about what being a citizen means.

James C. Scott illustrates that central to the power of the modern nation state was the project of making a society legible. The premodern state, he argues, "was, in many crucial aspects, partially blind; it knew precious little about its subjects." 25 The modern state, Scott shows, is based on "the concept of a uniform, homogeneous citizenship." ${ }^{26}$ It aims to make the populace readable and therefore more governable. Part of the project of creating this legibility involved creating a uniformity of customs, viewpoints, laws, forms of taxation, and measures. Such uniformity gave the state a synoptic view of its citizens. State officials advocated uniformly laid out and navigable cities, standardized surnames, and a "uniform homogeneous, national administrative code." ${ }^{27}$ This move toward standardization and legibility coincided with a new conception of the state's role, which was aimed at the improvement of all members of society. These attempts by the state to make its populace readable involve, Scott contends, simplification since the representation 
of an existing social community can only be done through a "schematized process of abstraction and simplification." 28 It involved the "discovery of a society as a reified object that was separate from the state and that could be scientifically described." ${ }^{29}$

Constitutions can be seen as a way modern states strive to create this legibility. Thus, constitutions represent a means by which the state-or those stakeholders whom the process empowers-portrays and projects an image of itself and the way that it wishes to be understood. This process of creating legibility does not however simply describe but also shapes the people to fit the state's categories. ${ }^{30}$

Understanding constitutions as expositions of state ideology sometimes assumes that there is some kind of consensus before the constitution is made, "understood in 'thick' terms of cultural, national or religious homogeneity, or in 'thin' terms of shared liberal political culture." ${ }^{31}$ Yet such a consensus does not exist in deeply divided societies such as Egypt, which are struggling over the question of what the nation is and what it believes in. In some cases, delay in writing a constitution happens because the parties involved want to avoid difficult decisions about the nature of the nation state. By putting off the decision about precise constitutional commitments, overt conflict is avoided. For example, one of the reasons why the Israeli Knesset decided in 1950 to refrain from writing a constitution was the conflict between secular and religious definitions of the Jewish state. Fearing that establishing a constitution would exacerbate tensions, it was indefinitely delayed. ${ }^{32}$ However, while delaying the writing of a constitution can put off conflict, constitution writing can also be used as a tool by which different actors use the constitution to limit the actions of the opposition. It can also operate as a means by which political actors define - and limit - the boundaries within which their political antagonists can operate.

The lack of preconstitutional consensus does not mean that constitutions in deeply divided societies cannot be read as ideological statements. In fact, constitutional texts can be read as declarations that provide insight into the concerns that dominate the political scene at a particular moment. In addition, they can be read as attempts to channel the formation of values in a particular direction and silence dissent. Seeing constitutions as representative of ideological commitments does not also assume that ideology is neatly applied in the constitutional process. Brown suggests that we should understand constitutions not so much as a product of design but rather as a product of a fraught process of bargaining. ${ }^{33}$

Brown points out that constitution writers have become increasingly verbose over the twentieth century. Among the chief reasons for the extension 
in the lengths of constitutions is because long sections describing the ideology of the state are included. Often, he shows, such proclamations carry little legal weight due to the wording. Yet, he argues, "they are not designed to limit the government. Instead, they serve notice that an ideological orientation represents not a transient policy direction but a defining feature of the state." ${ }^{34}$ Saïd Arjomand writes that constitutions are "important as transcendental justifications of political order." ${ }^{35}$ In the wake of the Soviet Constitution of 1918, he asserts, "we witness the advent of a new genre, the ideological constitution, whose central goal is not the limitation of government but the transformation of society according to a revolutionary ideology." ${ }^{\text {"36 }}$ The ideological constitution, has lengthy preambles or ideological statements. ${ }^{37}$

\section{Religion, Culture, and Citizenship in State Formation}

One of the underlying assumptions of our current political order is that citizenship forms the normative basis for the direct relationship between individuals and the modern nation state. The legitimacy of the modern nation state depends on the participation of the citizenry and a relatively strong commitment on the part of citizens. It is also assumed that this relationship gives rights to the citizen. Yet citizenship as bestowed upon the citizen by the state also makes certain demands and conveys both rights and obligations.

For Wael B. Hallaq, the state asserts its sovereign will, which "knows only itself, deferring to nothing but itself," over the citizen. ${ }^{38}$ Thus, to be a citizen means acknowledging that one lives under a sovereign will and that the state is supreme. The citizen, Hallaq contends, is a "subjectivity fashioned in the service of a state." ${ }^{39}$ Fashioning the citizen involves fashioning the question of religious identity, what religion is, which religious identities are to be given a status in the nation, and which religious identities are not accorded a status. This is critical to the project of modern states regardless of whether such states are defined as secular or Islamic.

Citizenship is often contingent on the concept of a national culture that binds citizens of a nation together and forges their relationship to the state. David Lloyd and Paul Thomas argue that culture "occupies the space between the individual and the state" so that the state can lay claim to universality and representation. ${ }^{40}$ The state, they maintain, "is an exemplary institution of the people, ideally moving them towards the realization of their own essence." Cultural formation ends up "forming citizens for the modern state." ${ }^{42}$ The articulation of a national culture has aided the formation of new states such that Matthew Arnold in 1867 stated that "culture suggests the idea of the State." ${ }^{33}$ Wael B. Hallaq asserts that law, in representing the state's will, must 
use the concept of culture and that "through the sovereign will's legal manifestation the state does not stand independently of culture. In other words, the state produces and thus possesses its own community." ${ }^{44}$

Raymond Williams argues that the idea of culture in the sense that we use it today in terms of "a whole way of life" or as an "abstraction and an absolute" came into English thinking during the Industrial Revolution, which produced new cultural relationships and changes in thought and feeling. ${ }^{45}$ The articulation of culture as a way of life in an abstract sense has facilitated the development of the concept of a national culture that binds a national community. This is an intrinsic part of state formation. Tomoko Masuzawa shows that the idea of culture that was tied to the destiny of the whole nation developed in the German-speaking world in the nineteenth century. The construction of such a thing as German culture aided the formation of the unified German state in $1871 .{ }^{46}$

Even in seemingly secular societies, the position that society takes toward religion forms a key component in how the culture of that society is defined. Secular societies are not neutral toward religion, but make particular institutional decisions to place it in particular places. Thus, religion-in terms of the variety of ways religion is managed, theorized, and mythologized even if that involves the supposed absence of religion from the public sphere-is a key part of culture.

If the concept of a national culture legitimizes the state's claim to represent its citizens, the concept of a national will is also central to that legitimacy. The assertion that the national will is central to the legitimacy of the political process has become ubiquitous in contemporary political events. During President Erdogan's crackdown on the attempted military coup by a faction of the Turkish Armed Forces in 2016, he stated that those people who turned out to protest the attempted coup represented the "national will" and represented "the people." ${ }^{47}$ Likewise, in discussions about the 2016 referendum over Britain's withdrawal from the European Union, the concept of the national will was frequently invoked. The commentator David Dimbleby stated that the "British people have spoken and the answer is 'we're out!"' In postreferendum Britain, references to "the will of the people" became a means of trying to silence dissent and disagreement. ${ }^{48}$

After the ouster of the Egyptian president Hosni Mubarak in 2011, a statement from the Faculty of Law at Cairo University called on Mubarak to "comply with the will of the nation," and, among other actions, draft a new constitution.$^{49}$ Similarly, during the military coup against the government of President Muhammad Mursi in 2013, Mursi was criticized for having ignored the calls of "the people." The assertion that there is such a thing as a 
collective will has become important for the modern state. Talal Asad argues that the modern politics of nation states are predicated on the belief that there is "such a thing as a homogeneous nation, that a homogeneous nation has the right to absolute independence represented by a state, and that the state must reflect the nation's singular personality." ${ }^{50}$

In Egypt, during the coup against Mursi, a common complaint was that he did not represent and act for all Egyptians. Asad points out that the idea that an elected president could be the leader of all Egyptians was never questioned. He asserts that an elected president "responds to the conflicting interests of fellow citizens by yielding to those who exert effective pressure on his government." ${ }^{\text {"1 }}$ Elections, however, cannot express the common will since elections take place because such a common will does not exist. It is precisely because of diversity that democracy has emerged, Asad argues, "for addressing the ineradicable presence of difference, disagreement, and mutual hostility within the modern state with minimum damage." 52

The expectation that the national will should and could be represented was expressed in common conceptions about the function of the constitution in Egypt. The constitution was not only seen as something that could establish the boundaries within which sectors of the state and its various institutions could operate to facilitate the workings of the political system. Rather, the constitution was expected to be a kind of embodiment of the national will and an expression of what being Egyptian means. This explains the heightened emotion with which the constitution was treated and why clauses relating to identity and to religion were subject to so much more debate. This is in part why the subject of the constitution emerged as so contentious and why such importance was attached to clauses that seemed to speak to the idea of a national character and identity. This helps explain why the constitution was abolished, written, abolished, and written again in the space of three years.

Constitutions can be seen as key moments whereby this notion of a totalizing national culture is asserted. Earlier Egyptian constitutions served similar purposes, but they were less developed in this respect. It was not until 1956 that the Egyptian constitution was drafted in the name of "We, the Egyptian people." Since then, Egypt's constitutions have become more and more detailed and verbose in articulating what Egyptian culture is and which understanding of Egypt's past it purports to uphold.

This concern with using the constitution as a form of representation of the Egyptian body politic can be seen in the texts of the preambles to the Constitutions of 2012 and 2014. Both, particularly the latter, are grandiloquent in their claims to represent the people of Egypt and to speak for 
the nation's history. The preamble to the 2012 Constitution implied that, through the revolution of 2011, the people of Egypt had "recovered the spirit of our great civilization and the fragrance of our radiant history." ${ }_{33}$

The preamble of the 2014 Constitution, however, outdid that of the 2012 Constitution in the extent of its claims to represent Egyptian society. The preamble to the Constitution of 2014 states: "We are now writing a constitution that represents the dream of generations for a thriving and cohesive society and a just state that realizes the present and future ambitions for the individual and the community." ${ }^{54}$ It would, the constitution declared, "treat the wounds of the past," and "protect the homeland from everything that might threaten it or threaten its national unity." ${ }^{35}$ In January 2014, the newspaper al-Ahram referred to the constitution as a constitution "for all Egyptians" and linked the constitution to Egypt's contribution to human kind and the world. ${ }^{56}$

While the universalizing language claiming to represent all Egyptians is evidenced by the word "our" in both the 2012 and 2014 Constitutions, the 2014 preamble is more assertive in its claim to represent the will of the people. It states: "We, the citizens, women and men, we the Egyptian people, sovereigns in a sovereign homeland, this is our will (hadha iradatna). This is the constitution of our revolution. This is our constitution." ${ }^{57}$ The writers of the constitution sought to appropriate the legitimacy of the 2011 revolution and state that the January 25 revolution, which ousted Mubarak, and the June 30 revolution, which ousted Mursi, together allowed Egypt to regain its "independent will." The preamble also says that "the Revolution of January 25-June 30 is unique among the great revolutions in the history of humankind on account of the extent to which the people participated, estimated to be tens of millions. It is also unique on account of the prominent role played by the youth who are striving for a rising future." 58 It also says that "the popular will was protected by the people's army and with the blessing of al-Azhar al-Sharif and the national church." ${ }^{59}$ In so doing, it asserts a continuity between the ouster of Mubarak and the ouster of Muhammad Mursi.

\section{Managing Religion}

Much academic literature about Egypt and its constitutions has charted a process of increasing Islamization over the twentieth century. The Constitutions of 1923 and 1956 were praised for their secular nature. This was done on account of the absence of any reference to the sharia and because both constitutions made a commitment to religious freedom. This is despite the 
fact that both constitutions stated that Islam was the religion of the state. The description of both constitutions as secular was based on Peter Berger's more commonplace definition of secularism, which defines secularism as involving aspects of society being separated from the domination of religious institutions and symbols. ${ }^{60} \mathrm{Gamal}$ 'Abd al-Nasser, under whose presidency the Constitution of 1956 was promulgated, has been described as a man of the future, an "apostle" of "nationalism, socialism, and modernization," whereas mullahs, monks, and priests, "with their dogmas, rites, and hierarchies, were creatures of an increasingly irrelevant past." ${ }^{61}$ The secular nature of the 1923 and 1956 Constitutions was, it was argued, undermined by the Constitution of 1971, which made a formal commitment to the sharia and marked what has been referred to as religion's political ascendancy. ${ }^{62}$ This reversal of the secular nature of Egypt's constitution was seen as catastrophic for women and the Copts. Similarly, the Constitution of 2012 was portrayed as threatening to the secular nature of Egypt, a threat that abated with the suspension of the Constitution of 2012 and the promulgation of the Constitution of 2014.

Such discourse about Egypt's constitutions assumed that the project of directly defining the religious and the secular is possible. Claims about the relative secular or religious nature of a constitution assume that religion can be empirically measured and that the boundaries between what religion is and what it is not can be easily drawn. They also assume a specific relationship between past and present. The assumption is that the constitution is modern because it is secular and that any attempt to insert Islamic law reverses the modern nature of the constitution. The insertion of premodern legal norms into a statement on the sharia is seen as detracting from-or undermining - the constitution's modernity.

Hussein Ali Agrama has pointed out that the question of whether Egypt is a secular or religious state has dominated discussions about modern Egypt. He argues that one of the problems with the question is that it does not tell us about the criteria we use to define a secular state. He maintains that, ultimately, it is not possible to say whether Egypt is a secular or religious state. The question of Egypt's secular or Islamic nature "is rather a question whose persistence, force, and irresolvability expresses the peculiar intractability of our contemporary secularity" (Agrama's italics). ${ }^{63}$ Thus, for Agrama, the very query into whether something is religious or secular lies at the heart of modern secularism.

Agrama's discussion of secularism builds on the thought of Talal Asad who maintains that it is only possible to approach the secular indirectly. Differentiating the concept of the secular from the political project of secularism, 
he argues that the "secular" and the "religious" are not essentially fixed categories and that the "secular ... is neither continuous with the religious that supposedly preceded it . . nor a simple break from it." ${ }^{64}$ The secular is "a concept that brings together certain behaviors, knowledges, and sensibilities in modern life." ${ }^{65}$ What is distinctive about secularism, he contends, is "that it presupposes new concepts of 'religion,' 'ethics,' and 'politics,' and new imperatives associated with them." ${ }^{60}$

The idea that the secular brings together certain sensibilities and that concepts such as religion and politics become associated with new imperatives allows for the jettisoning of the idea that secularism is the absence of religion and Islamism is its presence. This circumvents the problems that are involved in narrating Egypt's constitutions in terms of the number of references they do or do not make to religion. Viewing secularism in terms of a collection of different sensibilities and assumptions means that, even when religion is present, the way that religion works, is seen, and is invoked by political actors is filtered through those very assumptions.

Agrama questions whether there has been an Islamization of the law in Egypt since the promulgation of Article 2 of the 1971 Constitution, which made a commitment to the sharia. In fact, he contends, the law has come to conform to secular liberal expectations of religion in different ways. He uses the case in which a hisba (which refers to the right of an individual to bring a case against someone if that person sees the other person neglecting what is commanded and practicing what is forbidden within Islam) was brought against Nasr Abu Zayd in 1995. ${ }^{67}$ This case resulted in Nasr Abu Zayd being declared an apostate, which meant that he was forced to divorce his wife. Much literature on the case of Nasr Abu Zayd portrays his indictment as an example of a creeping Islamization of Egyptian law and society. ${ }^{68}$ However, Agrama argues that the use of hisba here was not a sign of the Islamization of law but rather a sign that the sharia has come to conform to liberal law since it represented a moment that reflected—and perhaps reinscribedthe power of the state to decide what was religious and what religion's role should be. This was further enhanced when the state limited the right of hisba to state officials. ${ }^{69}$

Khaled Fahmy has critiqued Agrama's discussion of hisba, showing that it was an integral part of the functioning of Islamic empires before modernity and maintained through violence. ${ }^{70}$ Indeed, 'Abd al-Hamid al-Ghazali (d. 1111) and Ahmad ibn Naqib al-Misri (d. 1368) discussed the question of whether hisba should be limited to officials of the ruling polity. ${ }^{71}$ While both agreed that this was not the case, al-Misri did state that intimidation and threatening to strike someone "requires the caliph because it may lead 
to civil disorder." ${ }^{\prime 2}$ This raises the question of whether limiting the right of hisba to state officials is entirely the product of what Agrama terms "modern secular power."

Yet Agrama's illustration of what the modern state does is particularly compelling. He sees secularism less in terms of the absence or presence of religion and argues that "one way to think about the active principle [of secularism] is to see the state as promoting an abstract notion of 'religion,' defining the spaces it should inhabit, authorizing the sensibilities proper to it, and then working to discipline actual religious traditions so as to conform to this abstract notion, to fit into those spaces, and to express those sensibilities." ${ }^{33}$ However, this does not result in any finite resolution since the process of drawing the line between religion and politics is continuous and indeterminable so that what best characterizes secularism is "an ongoing, deepening, entanglement in the question of religion and politics" (Agrama's italics and bold). ${ }^{74}$ Thus, for Agrama, it is more a question of how the secular is renegotiated and how the state manages, disciplines, and defines religion and determines the institutional mechanisms through which this is done. ${ }^{75}$

Understanding secularism as the way in which the state defines what constitutes the religious and the civil, along with seeing the parameters for this definition as subject to ongoing renegotiation, allows us to think less in terms of secularism as a particular model for state and society and more in terms of the variety of religion-state relationships that can be continuously reformulated. This is useful for thinking about Egypt's constitutions which continually draw the line between the civil and the religious in different ways.

Yet understanding secularism in such a way is in danger of making the term "secularism" lose all its explanatory purchase since it implies that all states or political actors who hanker after state power are somehow secular. While Andrew March finds much that is productive in Agrama's description of the ways in which religion is a means by which the state expands its power, he criticizes Agrama for reifying secularism and for portraying secular power as an agent that itself acts directly on the world rather than something deployed by agents or institutions. ${ }^{76}$ In addition, he criticizes Agrama for not limiting himself to saying that secularism is one way in which religion becomes politicized, but instead saying that "it is secularism itself that makes religion into an object of politics." 77

Gregory Starrett points out that defining the secular as a means by which the state exerts control over religion actually creates conceptual problems. If, he asks, "the government of Iran exercises more control over religion than the government of the United States, does that mean that Iran is a more secular place than the United States?" ${ }^{\text {? }}$ He contends that "the secular's usefulness 
as an analytical concept is deeply suspect" since the secular is precisely characterized by the fact that it cannot be pinned down. ${ }^{79}$ Thus, he argues, the significance of the secular lies in the way that it functions rather than what it describes. Starrett therefore advocates that one should treat the secular as a normative category rather than as a descriptive one..$^{80}$ Malika Zeghal has pursued this approach in her discussion of debates about religion and state in Tunisia during the Arab Spring. She points out that discourse about secularism and Islamism shows how each camp in the debate reified the other. She argues that a look at Islamic narratives on secularism helps "anchor 'Islamism' and 'secularism' as political identities and constituencies." ${ }^{81}$ An examination of such narratives about secularism shows the ways in which the differences between parties in Tunisia focused on political procedures and competing ways of life more than they did on "blueprints for a social and political order." 82

Starrett is correct to emphasize the importance of looking at the secular from the perspective of the user of the adjective. Such an approach can manifest the various and complex ways it is used and defy common expectations. Yet answering Starrett's question of how one addresses countries that exercise "more" control over religion than others, would involve defining the religion that one is exercising more or less control over. In addition, saying that the secular cannot be used descriptively, but can only be understood normatively, is the same as saying that similarly contested concepts such as religion, culture, modernity, or the West cannot be used descriptively and can only be understood normatively. Yet Asad says the idea of the "West" is not simply a "Hegelian myth," but something that "informs innumerable intentions, practices, and discourses in systematic ways." 83

It seems that Starrett's disentanglement of the descriptive and normative senses of the secular, while important, might not easily be done. This is also because those who use secularism in the normative sense actually need to do what Agrama points out is so central to "secular power," that is, draw the line between religion and politics. Even according to the common definition of secularism - that it is the process by which state and society become liberated from the influence of religion-before state and society can be liberated from religion, it is necessary to determine what it is that state and society are going to be liberated from. Thus, a decision must be made about what constitutes religion.

Yet March's critique that Agrama's "secular power" appears to be everywhere as an operative agent rather than something deployed by particular agents or institutions raises an important question about secular power's implied ubiquity and about its lack of analytical purchase. The question of 
whether it is secularism itself that makes religion into an object of politics or whether secularism is merely one way of making religion an object of politics is best addressed in further scholarship. Here, I would like to posit that constitution making is one way that religion is made into an object of politics or, to use Tamir Moustafa's term, the means by which religion is "constituted." Thus, constitutions can be seen as one institution through which what Agrama terms "secular power" is deployed. This resists the potential overreach of "secular power" while taking one of its central definitions, the very question of drawing the line between religion and politics and of demarcating different boundaries, seriously.

\section{Rethinking Islamism}

Here, I focus on an examination of the modern state's project-be it secular or religious in the more common sense of the word—of making religion into an object of politics. Whether this is what Agrama terms "secular power" or simply what modern states do is a matter of debate. In any case, rather than identifying the differences between secularism and Islamism, it is useful to think in terms of what secularism and Islamism-and secular and Islamist constitutions-have in common, specifically that both involve the state's management of religion. This involves deciding what acts, rights, and freedoms count as religious. Islamism takes a specific stand on religion. So does secularism. Contrary to common assumptions, secularism is not neutral with regard to religion: positively endorsing a political space that is absent of religion is not showing neutrality toward religion, but is rather adopting a particular position toward it. Thus, one of the things that secular and Islamic states do in regulating religious tolerance or religious freedom - and its limitations - is to define what religion is, which manifestations of religion are orthodox, which are heterodox, and what the relationship between religion and culture is. Constitutional texts are key to establishing the parameters within which particular understandings of religious identity, religious authority, and national culture are applied.

Such an approach casts the phenomenon that we call "Islamism" in a very different light. Many contend that political Islam should be understood as an attempt to establish an Islamic state and to implement the sharia. In this respect, an Islamist is someone who thinks that Islamic ideas, concepts, and legal norms should be referred to and applied in contemporary Muslim states. Likewise, Islamism, as others have argued, refers to thinkers and activists who claim that Islam is an all-embracing ideology for state and society and that Islam needs to be expressed politically. The contemporary 
Islamic thinker Yusuf al-Qaradawi (b. 1926), for example, states that "Islam cannot be anything except political," and that the "character of Muslims" also "cannot be anything except political." ${ }^{84}$

Understanding Islamism in terms of a movement that advocates the political expression of Islam allows for the inclusion of a wide range of thinkers who have differing attitudes about what kind of political system this would entail. While Islamists are preoccupied with state power, this does not mean they have a particular-or the same-image of the state in mind or that it should be a model of the Islamic caliphate. Islamists encompass a wide range of thinkers and activists with varied ideas about democracy, the Islamic state, gender, citizenship, and religious authority.

In calling for Islam to be expressed politically, it is often assumed that the particular relationship between religion and politics that is being called for simply has to be retrieved from premodern history and reapplied in the modern period. Many Islamists are concerned that the modern Islamic world has been disconnected from the premodern Islamic order. This premodern Islamic order constitutes a time in the past, most often the period of the Prophet and the rightly guided caliphs (610-661), in which Islam's political nature is deemed to have been perfectly realized. Such a perspective holds that this disconnection from Islam's past culminated in the importation of Western civil and criminal law. Political Islam calls for the reversal of this secularization and for the application of Islamic law assuming that it is the past that has to be retrieved, although what aspect of the past is to be revived and how is contested among Islamists themselves. It is this relationship with the past that has often been taken at face value by critiques of Islamism, which also assume that Islamists simply want to retrieve the past and that in being retrieved, this past will be imposed upon the present.

Such definitions of Islamism imply that Islamism constitutes an aberration or a departure from modernity. Such definitions assume that when something like an Islamic legal norm or principle is reintroduced, the norm or principle is simply the agent of change for those who are subject to it, but that the norm or principle itself remains unaltered. Yet a reintroduction of something alters both the receiver and the giver. Islamism is a modern project that has in many ways been constituted by the modern nation state's project to delineate the relationship between religion and politics even if a not dissimilar delineation was important for classical jurists. Islamism should therefore be conceptualized with reference to the means by which it has absorbed particularly contemporary concerns and the ways that Islamic norms and laws have been reworked in light of those concerns. 
Thinking about Islamism and the contemporary Egyptian state in this way breaks down the binary between the Islamic and the secular. This is the binary through which much of Egyptian politics has-and continues to be-framed. The idea that there is an ongoing conflict between secular and Islamic forces is central to Egypt's coverage of itself and to international coverage of the country. Yet, as will be shown in this book, the agendas and the motivations of many of the key players and groups cannot be understood as Islamic or as secular. Dispensing with the binary will allow us to see what really is at stake in the constitutional debates about religion and the relationship between religion and the state in contemporary Egypt.

A demand for Islam and for the sharia is also a demand for the state's intervention in the relationship between religion and politics. A call for secularism is also a call for states to intervene and assign a particular place to religion. A request by the populace for Islamism and for secularism constitutes a request for the state to determine who gets to speak for the religion that is being managed and defined and what the relationship between identity and difference is.

Thinking about Islamism in this way is not to deny that there are important distinctions between the kind of state envisaged by, for example, Islamists like members of the Muslim Brotherhood and the kind envisaged by groups that identify themselves as secular-at least in the traditional sense. Nor is it to dismiss the political threat that radical groups like ISIS and al-Qaeda pose. However, it is to say that Islamism itself is varied and that many Islamists are not so much concerned with the concept of jihad and who the enemy is, but with questions of modern governance. Clearly, the ways in which particular secular and Islamist groups draw the line between religion and politics will differ not only from each other but also among themselves. However, all states or state actors are involved in the modern imperative to manage religion and manage what counts as religious, even if they do so in distinct ways.

The distinction between religion and politics occurred in premodern Islamic governance. Abdullahi An-Na'im points out that, in Islamic history, religious and political authorities were differentiated and separated. Most regimes, he argues, could be characterized as a mixture between separation and convergence. There was, he claims, no single Islamic model for state and religious institutions. ${ }^{85}$ Agrama acknowledges that there are a number of instances in medieval Christian Europe and premodern Islamic history in which various writers and political actors delineated some kind of separation of spheres of authority. Yet Agrama states that there are different issues at stake in the modern distinction between religion and politics and that 
such concerns with the separation of temporal and spiritual authority arose under very different presuppositions and "elicited and mobilized very different desires and anxieties." ${ }^{86}$ Agrama contends that defining the boundary between religion and politics in the context of the modern state acquires a "distinctive salience," and is particularly bound up with modern secular power. Defining the boundary between religion and politics in the contemporary context has "inescapable consequences for how essential freedoms are identified, selves and their motives defined, and ways of life can be lived." ${ }^{87}$

Yet, while Agrama powerfully illustrates what such anxieties are in contemporary Egypt, he does not discuss the ways in which those particular stakes are new or what those stakes were in different contexts in premodern Islamic history. Indeed, such a delineation did have its own particular-albeit different-salience for classical jurists, as chapter 2 will show. It is this distinction between past and present, between modern secular power and what went before, that is in danger of effacing the subtle differences and similarities between premodern sharia and its application in the contemporary context.

Thinking about modernity as a different set of stakes and sensibilities is a useful way of discerning what is modern about the project of Islamism. However, it is also important to address the ways in which those stakes and sensibilities inherit premodern concerns. I maintain that, when the sharia is applied as modern Islamic state law through constitutional commitments, the sharia becomes embedded in the aspirations of the modern nation state in ways that constitute both continuity and change.

In this chapter, I have called for seeing constitutions in terms of their role as ideological statements through which the state claims to represent its citizens. Constitutions play an important role in the foundation of new political orders. They constitute a revolutionary act which both consolidates and puts an end to the revolution that made the constitution possible. Constitutions also provide a map of the relationship that the state is to have with its citizens. Thus, utilizing the work of James C. Scott and Timothy Mitchell, I have argued that constitutions have come to operate as signifiers that announce what national identity and national culture are and declare the nature of the relationship between citizens and the state. They are used by those who control the state to exhibit to the rest of the populace what it stands for. They thus serve as means of control by creating certain expectations about what being a citizen entails.

The concept of citizenship forms the normative basis for the direct relationship between individuals and the modern nation state. Citizenship is 
often contingent on the concept of a national culture in terms of a whole way of life that binds citizens of a nation together and forges their relationship to the state. The expectation that the national will should and could be represented was expressed in common conceptions about the function of the constitution in Egypt. This is why Egypt's constitutions were framed, in what Malika Zeghal, building upon Foucault, refers to as a "discursive explosion," in terms of how they spoke to the religious or the secular nature of the Egyptian state. ${ }^{88}$

However, secularism and Islamism cannot be understood in terms of the greater or lesser presence of religion, since this implies that such terms are self-evident. Here, recent theorizations of secularism that emphasize secularism is the process by which the relationship between religion and politics is constituted are useful. Looking at constitutions in terms of how they define the relationship between religion and politics allows us to think in terms of what secularism and Islamism - and secular and Islamist constitutions-have in common, specifically that both involve the state's management of religion. Dispensing with the Islamist/secular binary will allow us to see what issues are at stake in the constitutional debates about religion and the relationship between religion and the state in contemporary Egypt. 